\title{
Protocol
}

\section{Purifying Antibodies Raised against Xenopus Peptides}

\author{
Maya Z. Piccinni and Matthew J. Guille ${ }^{1}$ \\ European Xenopus Resource Centre, Institute of Biological and Biomedical Sciences, University of Portsmouth, \\ Portsmouth, Hampshire PO1 2DY, United Kingdom
}

\begin{abstract}
Antibody production for work in Xenopus involves the immunization of a host with an antigen, usually a Xenopus protein or peptide alien to the host. The antibody-containing serum, normally returned to the investigator by the company/bioresource unit where it was raised, is comprised of all proteins not used in blood clotting (coagulation) and all the electrolytes, antibodies, antigens, hormones, and any exogenous substances, such as drugs and microorganisms, that were in the blood. It is often necessary to separate the target antibody from the rest of the serum components to minimize nonspecific protein-antibody interactions in downstream applications (e.g., when performing western blotting). Most antibody production companies provide a column containing the peptide coupled to glass beads. A purification procedure for using this type of column (i.e., one that is based on controlled-pore glass beads) is described here.
\end{abstract}

MATERIALS

It is essential that you consult the appropriate Material Safety Data Sheets and your institution's Environmental Health and Safety Office for proper handling of equipment and hazardous materials used in this protocol.

Reagents

Antisera (see Protocol: Raising Antibodies for Use in Xenopus [Piccinni and Guille 2020a])

Caprylic acid (100\%)

$\mathrm{dH}_{2} \mathrm{O}$

Ethanol (100\%)

Guanidinium chloride (6 M)

$\mathrm{HCl}(10 \mathrm{~mm})$

$\mathrm{NaCl}(0.5 \mathrm{M}$ in $1 \times$ PBS $)$

PBS-azide ( $0.02 \%$ sodium azide in $1 \times$ PBS)

Phosphate buffered saline (PBS; Sigma-Aldrich P4417-50TAB [1 tablet/200 mL])

Potassium thiocyanate $(3.5 \mathrm{M})$

Sodium acetate (60 mm, $\mathrm{pH} 4.0)$

Sodium bicarbonate $(10 \mathrm{~mm})$

Equipment

Beakers and magnetic stirrers

\footnotetext{
${ }^{1}$ Correspondence: matthew.guille@port.ac.uk

From the Xenopus collection, edited by Hazel L. Sive.

(c) 2020 Cold Spring Harbor Laboratory Press

Cite this protocol as Cold Spring Harb Protoc; doi:10.1101/pdb.prot105619
} 
M.Z. Piccinni and M.J. Guille

Columns containing peptides coupled to glass beads

The column used for manufacturing the antigen is supplied to the user in the case of multiple antigenic peptides (MAPs) or can be made at the user's request for normal peptides. See Discussion.

Dialysis tubing closure clips (one for each end)

G-25 column $(1.5 \times 75 \mathrm{~cm}$; stored in PBS-azide $)$

Liquid nitrogen

Lyophilizer

Tabletop centrifuge

UV spectrometer

Visking tubing (18/32 inch diameter; preboiled and stored in 70\% ethanol)

\section{METHOD}

Antibody purification is usually carried out in three series of steps. First, the total IgG in the serum is isolated by caprylic acid extraction. Second, specific IgGs are isolated by affinity purification. Last, the affinity-purified antibodies are desalted on a G25 column.

\section{Caprylic Acid Extraction}

1. Mix $20 \mathrm{~mL}$ of $60 \mathrm{~mm}$ sodium acetate $(\mathrm{pH} 4.0)$ with $10 \mathrm{~mL}$ of antiserum in a beaker at room temperature.

2. Add $750 \mu \mathrm{L}$ of $100 \%$ caprylic acid to the mixture (for a final concentration of $2.5 \%$ ) while stirring.

3. Leave the mixture stirring until it turns white $(20-30 \mathrm{~min})$, and then centrifuge at $5100 \mathrm{~g}$ for $20 \mathrm{~min}$ at room temperature.

4. Transfer the supernatant into a fresh tube, and assay the total IgG present by UV spectroscopy. [One $A_{275}$ unit is $0.714 \mathrm{mg} / \mathrm{mL}$.]

\section{Dialysis}

5. Rinse $20-25 \mathrm{~cm}$ of preboiled $18 / 32$ inch diameter Visking tubing with distilled $\mathrm{H}_{2} \mathrm{O}$ for every $10 \mathrm{~mL}$ of starting material.

6. Clip one end of the tubing, and pipette the cleared supernatant through the other end, before securing the top with a second clip.

7. Place the tubing containing the IgG into $1 \mathrm{~L}$ of $1 \times \mathrm{PBS}$, and stir gently overnight at $4^{\circ} \mathrm{C}$.

8. On the following day, measure the $\operatorname{IgG}$ concentration of the solution inside of the tubing using UV spectroscopy $\left(\mathrm{A}_{275}\right)$.

Use the sample immediately for affinity purification or store it at $-20^{\circ} \mathrm{C}$.

\section{Affinity Column Purification}

The affinity column is prepared and run at room temperature by gravity filtration.

\section{Preparing the Column}

Before using the column for the first time, prepare it as described in Steps 10-15. This intensive cleaning procedure should also be used if the column clogs or stops binding IgG.

9. Equilibrate the column with $5 \mathrm{~mL}$ of $1 \times$ PBS.

10. Wash the column with five bead volumes of $6 \mathrm{~m}$ guanidinium chloride.

11. Wash the column with five bead volumes of $10 \mathrm{~mm} \mathrm{HCl}$. 
12. Wash the column with five bead volumes of $100 \%$ ethanol.

13. Wash the column with five bead volumes of $1 \times$ PBS.

14. Store the column at $4^{\circ} \mathrm{C}$ in PBS-azide, capped at both ends to avoid drying and inhibit bacterial growth.

\section{Purifying the Antibody}

15. Before use, equilibrate the column by washing it with three column volumes of $1 \times$ PBS.

16. Pass the IgG (sample from Step 8) through the column three times.

17. Rinse the column with 10 bead volumes of $1 \times$ PBS.

18. Rinse the column with 10 bead volumes of $0.5 \mathrm{M} \mathrm{NaCl}$ in $1 \times \mathrm{PBS}$.

19. Finally, rinse the column with 10 bead volumes of $1 \times$ PBS.

\section{Eluting the Antibody}

20. Add $3.5 \mathrm{~m}$ potassium thiocyanate directly onto the beads $1 \mathrm{~mL}$ at a time, for a total of $6 \mathrm{~mL}$. Immediately desalt the eluted antibody by passing it through a G-25 column (see Step 25).

\section{Cleaning the Affinity Column}

21. Following the antibody elution, wash the affinity column with 10 bead volumes of $10 \mathrm{~mm} \mathrm{HCl}$.

22. Wash the column with 10 bead volumes of $1 \times$ PBS.

23. Store the column in PBS-azide at $4^{\circ} \mathrm{C}$.

\section{G-25 Column Purification}

\section{Desalting the Antibodies}

The column separates the $\lg G$ from the salt, allowing the $\lg G$ to elute first.

24. To equilibrate the column, pass at least two column volumes of $10 \mathrm{~mm}$ sodium bicarbonate through the G-25 column.

25. Load the eluted antibody from Step 21 onto the equilibrated column at a flow rate of $2 \mathrm{~mL} / \mathrm{min}$.

26. Wash the G-25 column with 10 mm sodium bicarbonate until a peak in UV absorbance is visible, which corresponds to the antibody being eluted.

27. Allow the G-25 column to run with $10 \mathrm{~mm}$ sodium bicarbonate until a second UV absorbance peak is recorded, corresponding to the salt being washed off.

Figure 1 shows a representative elution graph.

28. Wash the column by passing an extra five bead volumes of $10 \mathrm{~mm}$ sodium bicarbonate through it.

29. Run two bead volumes of PBS-azide although the column, and store it in this solution at room temperature.

\section{Quantifying and Storing the Collected Fractions}

30. Assay the fractions collected by UV spectroscopy $(275 \mathrm{~nm})$ to identify those containing the IgG and to measure the IgG concentration.

One $A_{275}$ unit is $0.714 \mathrm{mg} / \mathrm{mL}$. The expected yield is $1-6 \mathrm{mg}$ of antibody for every $10 \mathrm{~mL}$ of starting material. See Troubleshooting.

31. Pool fractions that have a considerable amount of antibody, and aliquot into 100-mg lots. 
M.Z. Piccinni and M.J. Guille

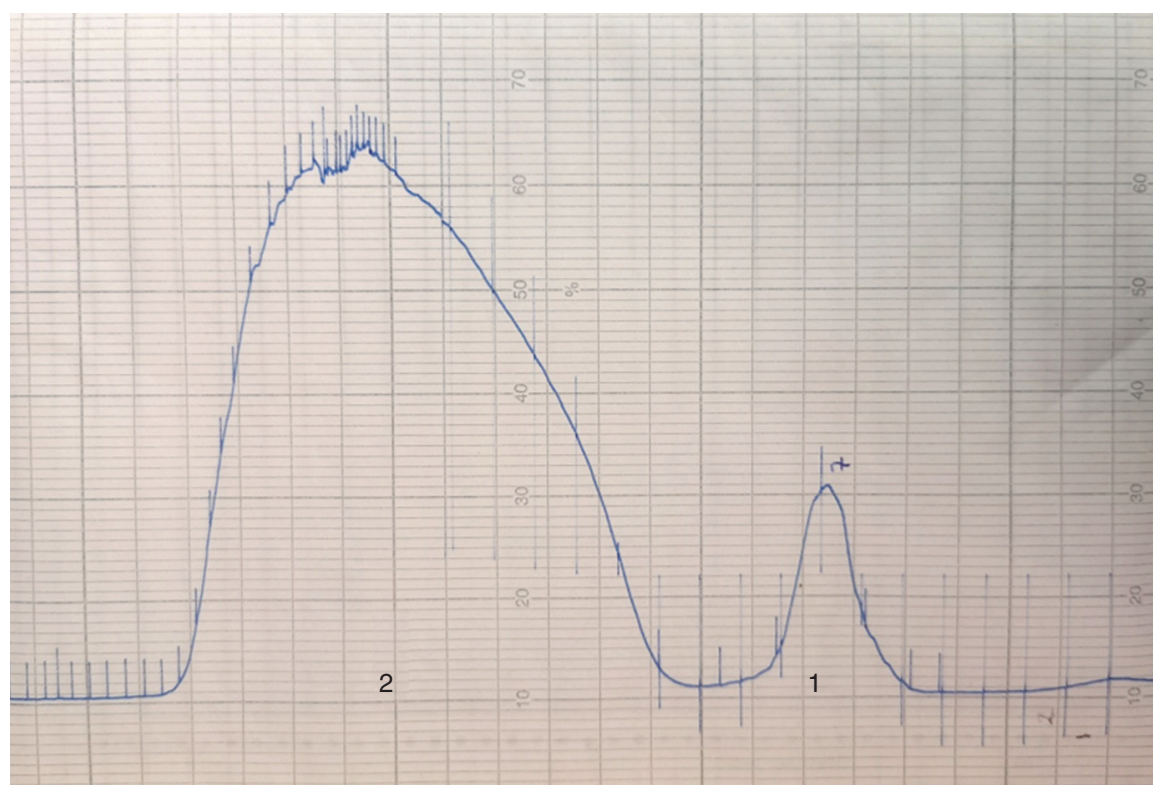

FIGURE 1. Typical elution graph from a G25 desalting column. Following equilibration of the column, the caprylic acid-treated serum was loaded onto the G25 column, in this case at a $2 \mathrm{~mL} / \mathrm{min}$ rate. The column separated the lgG, which was eluted first (1) from the salt (2). The eluted antibody was quantified by UV spectroscopy (at $275 \mathrm{~nm}$ ).

32. Snap-freeze the aliquots in liquid nitrogen, and lyophilize overnight (Ó’Fágáin 2004).

33. Store the lyophilized antibodies at $-20^{\circ} \mathrm{C}$ until further use.

The lyophilized antibodies will last for many years. They have many applications; for example, they can be used in the associated western blotting protocol that describes how to test the immune response of a host animal during antibody production (see Protocol: Assessing the Immune Response When Raising Antibodies for Use in Xenopus [Piccinni and Guille 2020b]).

Problem (Step 31): The yield of antibody is $>6 \mathrm{mg}$.

Solutions: A yield of $>6 \mathrm{mg}$ may be cause for concern, as there could be contamination from other proteins binding to the column. If this occurs, then proceed as follows.

1. Store either the flowthrough or the bound fraction containing your IgG on ice.

2. Wash the column as described in Steps 9-13.

3. Rerun the fraction containing your IgG on the newly washed column.

Problem (Step 31): The yield of antibody is $<1 \mathrm{mg}$.

Solutions: Should the IgG fail to bind to the affinity column, then a yield $<1 \mathrm{mg}$ would be expected. If this occurs, then wash the column as described in Steps 9-13.

The exact approach taken to purify antibodies varies only slightly depending on the type of immunogen, and hence column, used. Because most antibody production companies provide columns containing peptides coupled to glass beads, an antibody purification procedure for using this type of column (i.e., one that is based on controlled-pore glass beads) is described here. The convenience of 
having very robust columns based around controlled-pore glass beads is an advantage of using peptide antigens; however, the disadvantages of this approach are the risk of losing specificity due to the antigen's small size and the possibility that the peptide adopts conformations that do not resemble the conformation of the native protein (Trier et al. 2012; Lee et al. 2016). For larger proteins, the immunogen can be immobilized on a wide range of column matrices specifically designed for the purpose (e.g., beads carrying small organic compounds or inorganic metals [Hermanson 2013]); however, doing so does rely on sufficient immunogen having been produced initially.

\section{REFERENCES}

Hermanson GT. 2013. Bioconjugate techniques, 3rd ed. Elsevier, Amsterdam.

Lee B-S, Huang J-S, Jayathilaka LP, Lee J, Gupta S. 2016. Antibody production with synthetic peptides. Methods Mol Biol 1474: 25-47.

ÓFágáin C. 2004. Lyophilization of proteins. In Protein purification protocols. Methods in molecular biology (ed. Cutler P.), Vol. 244. Humana Press, New York.
Piccinni MZ, Guille MJ. 2020a. Raising antibodies for use in Xenopus. Cold Spring Harb Protoc doi:10.1101/pdb.prot 105585.

Piccinni MZ, Guille MJ. 2020b. Assessing the immune response when raising antibodies for use in Xenopus. Cold Spring Harb Protoc doi:10.1101/pdb .prot105593.

Trier NH, Hansen PR, Houen G. 2012. Production and characterization of peptide antibodies. Methods 56: 136-144. 


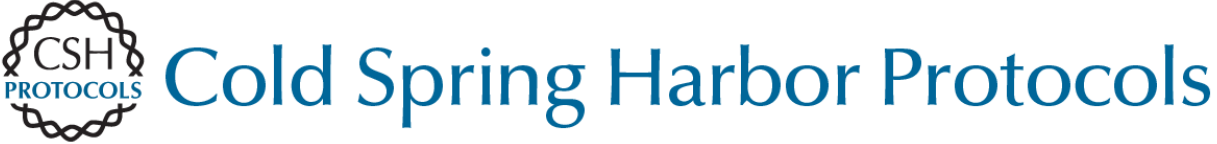

\section{Purifying Antibodies Raised against Xenopus Peptides}

Maya Z. Piccinni and Matthew J. Guille

Cold Spring Harb Protoc; doi: 10.1101/pdb.prot105619 originally published online January 3, 2020

\begin{tabular}{|c|c|}
\hline $\begin{array}{r}\text { Email Alerting } \\
\text { Service }\end{array}$ & Receive free email alerts when new articles cite this article - click here. \\
\hline $\begin{array}{l}\text { Subject } \\
\text { Categories }\end{array}$ & $\begin{array}{l}\text { Browse articles on similar topics from Cold Spring Harbor Protocols. } \\
\text { Affinity and Immunoaffinity Chromatography (57 articles) } \\
\text { Antibodies ( } 119 \text { articles) } \\
\text { Antibodies, general ( } 289 \text { articles) } \\
\text { Chromatography, general (134 articles) } \\
\text { Generating Antibodies, general (60 articles) } \\
\text { Handling Antibodies (43 articles) } \\
\text { Purifying Antibodies (18 articles) } \\
\text { Xenopus ( } 210 \text { articles) }\end{array}$ \\
\hline
\end{tabular}

